\title{
Isolation, Optimization and Characterization of Lipase Producing Bacteria from Abbatoir Soil
}

\author{
Hadiza Jamilu' ${ }^{1}$, Aliyu Hassan Ibrahim ${ }^{2}$, Suleiman Zubair Abdullahi' ${ }^{2}$ \\ ${ }^{1}$ Department of Applied Biology, College of Science and Technology, Kaduna Polytechnic, Kaduna \\ ${ }^{2}$ Department of Environmental Science, College of Environmental Studies, \\ Kaduna Polytechnic, Kaduna \\ E-mail: hadizajamilu123@gmail.com; aliyuibrahim@kadunapolytechnic.edu.ng
}

\begin{abstract}
Microorganisms can easily degrade agro-industrial wastes in a solid-state fermentation process thereby synthesizing many important commercial bio compounds including lipolytic enzymes. Screening different habitats for bacteria with lipase activity and optimizing its fermentation parameters with facilities effective production and usage in industries. In this study, soil samples from different Abattoirs in Kaduna metropolis were screened for presence of lipase positive strains culture medium parameters such as carbon source, inducers, nitrogen source, $\mathrm{pH}$, temperature, inoculums level and incubation period were varied for the purpose of optimization. Maximum lipase activity was recorded at 48hours incubation, this activity occurred in media containing groundnut peel and rice husk, supplemented with ammonium nitrate and urea which are the best carbon and nitrogen sources. The isolated bacteria were identified as Pseudomonas biochemically, the production, partial purification and characterization of lipase activity at different $\mathrm{pH}$, determination of molecular weight analysis. The lipase was partially purified up to saturation using ammonium sulphate precipitation spectrophotometric lipase assay was used for enzyme characterization. Lipases produced by pseudomonas have been used widely in pharmaceutical, food, pulp, textile, paper, leather industries among others due to their stability, selectivity and broad substrate specificity.
\end{abstract}

Keywords: lipase; isolation; characterization; abbatoir; soil

\section{INTRODUCTION}

Enzymes are highly efficient catalysts from biological sources which catalyse all synthetic and degradative reactions of living organisms. Enzyme was first reported in the second half of the nineteenth country and since then its usage has increased many folds in various industries.

Lipases (Triacyclglycerol acylhydrolases EC3.1.1.3) belong to a class of hydrolases that are specific for the hydrolysis of fats into fatty acids and glycerol at water-lipid interface. They are also capable of reversing the reaction in nonaqueous media and they are abundantly present in nature. Lipase was determined by Clade Bernad, 1856 in pancreatic juice as an enzyme that hydrolyzed insoluble oil droplets and converts them to soluble products. Different species of fungi, yeast, bacteria, animal and plants have been reported to be sources to lipase. However, microbial lipases have become cynosure of all eyes as a result of its numerous industrial application potentials, ease of culture handling and the ease for scale-up during production.

The 3D structure of lipases from different microbial sources are not exactly alike, they exhibit high sequence diversity. As a result, these enzymes are unique and specific to the type of bioconversion processes they catalyze, finding relevance in a wide array of industrial processes. They are found to be useful in catalizing various reactions synonymous to food, pharmaceuticals, medical and diagnosis, dairy, fatty acid, leather, cosmetic, detergent, beverage and paper industries. Lipases occur in plants, animals and microorganisms (Martins et al., 2008; Roveda et al., 2010), but only microbial lipases can be produced in large-scale (Roveda et al., 2010; Qamsari et al., 2011).
Microorganisms are generally preferred to plant and animal as source of industrial enzymes because their production cost are low, enzyme contents are more predictable and controllable, moreso, easy availability of raw materials with constant composition for their cultivation. The presence of potential/harmful materials like phenolic compounds (in plants), enzyme inhibitors in plant and animal tissues limit the use of plant and animal sources in enzyme production. There is a demand to replace traditional chemical processes with advanced biotechnological processes involving microorganisms and enzymes, such as lipase. All these not only provides an economically viable alternative, but also are more ecofriendly (Panersar et al., 2016).

The great commercial importance of lipases is due to their wide range of applications in detergents, pharmaceuticals, foods (cheese and tea), pulp and paper, textiles, tanneries, cosmetics, biodiesel and wastewater treatment (Messias et al., 2011; Roveda et al., 2010; Yan et al., 2014).

Microbial lipases are mainly produced by submerged fermentation (SmF), which is a well-known operation in which the engineering aspects are currently fully developed. However, solid-state fermentation (SSF) has shown some advantages for enzyme production compared to $\mathrm{SmF}$, even at a commercial scale (Thomas et al., 2013). It only needs a low percentage of free water to be conducted and it uses low cost substrates such as agricultural wastes, which act both as a source of nutrients for the fermentation process (Martins et al., 2008; Messias et al., 2011), and as a support for the growth of microorganisms. 
Chahinian and Sarda (2009) opined that lipases are capable of hydrolyzing water-insoluble esters and show a different distribution on the hydrophobic amino acids surrounding the active site.

Hydrolysis Reaction of lipases naturally catalyze ester bond of tri-, di-, and monoglycerides into fatty acids and glycerol as shown in Figure. 1, they are also active on a broad range of substrates. In all cases, the reaction is carried out at the interface of a biphasic system reaction. This biphasic system results from the presence of an immiscible organic phase, containing the hydrophobic substrate in water. First lipases were isolated by Eijkman from Bacillus prodigiosus, Bacillus pyocyaneus, and Bacillus fluorescens, currently known as Serratia marcescens, Pseudomonas aeruginosa, and Pseudomonas fluorescens, respectively (Eijkmann,1901). Nowadays, it is recognized that lipases are produced by various organisms, including animals, plants, and microorganisms.

\section{MATERIALS AND METHODS}

\section{Wastes Sample Collection}

All the substrates such as wastes of sugarcane bagasse, wheat bran, rice bran, groundnut shell and cassava peel used for solid fermentation were purchased from local market namely (Central Market Kaduna and Kawo Market, Kaduna).

All other chemical substrates used in this study are of analytical grade purchased from chemical suppliers while the mutant strain of Pseudomonas sp was isolated from soil samples grown on nutrient agar at 370C from $24 \mathrm{hrs}$ for bacteria and potatoes dextrose agar at room temperature for $72 \mathrm{hrs}$ for fungi.

\section{Sources of soil samples for Isolation of lipolytic organisms}

Different locations were selected for the search of alkaline lipolytic organisms from Abbatoirs in Kaduna metropolis. Mainly soil samples were collected from two different locations namely: Kawo Abbatoir and Central Market Abbatoir respectively in properly labeled pre - sterilized bottles. All samples were immediately transferred to laboratory and stored at 4 oc until analysis.

\section{Screening of Lipase Producing}

The Lipase producing bacteria was screened using Tributyrin Agar (TBA) culture medium supplemented with Tributyrate as a substrate on agar plates. The media was prepared according to manufacturer's guide. After autoclaving the media was cooled and dispensed into sterile plates. The pure isolates well inoculated on the plates and incubated $24 \mathrm{hrs}$ at $35 \mathrm{oc}$. The colonies with a clear zone around it (lipolytic activity) was selected for further studies.

Medium Preparation for Solid State Fermentation (SSF) The SSF experiments was carried out in $250 \mathrm{ml}$ Erlenmeyer flasks containing $10 \mathrm{~g}$ of solid substrates, 1.0 $\mathrm{ml}$ of micronutrient solution having composition of $5.0 \mathrm{~g} / \mathrm{L}$ K2HPO4, 1.0 g/L MgSO4.7H2O, $1.98 \mathrm{~g} / \mathrm{L} \mathrm{MnCl2.4H2O,} 0.25$ g/L CuSO4.5H2O and 103 0.29 g/L ZnSO4.7H2O with pH 7.0. The final substrate moisture content was adjusted to $50 \%(\mathrm{v} / \mathrm{w})$ using distilled water. After sterilization by autoclaving, the flasks were cooled and inoculated with 1.0 $\mathrm{ml}$ of inoculum $(10 \% \mathrm{v} / \mathrm{w})$ and incubated at $37^{\circ} \mathrm{C}$ for 48 .

\section{Optimization of Fermentation Process for lipase production}

Factors like selection of solid substrate, effect of oil as inducer, effect of supplementary carbon source, nitrogen source, inoculum level, incubation time, initial $\mathrm{pH}$, incubation temperature and initial moisture content affecting the secretion of lipase by the isolated organisms under solid state fermentation was optimized by adopting search technique (Tunga et al.,1998) i.e varying parameters one at a time. Each optimized parameter was incorporated in the subsequent experiments.

\section{Selection of Solid Substrate}

Different wastes of sugarcane bagasse, wheat bran, rice bran, and groundnut shell and cassava peel were used as solid substrates to study their effect on the production of lipase.

\section{Determination of Oil as Inducer}

The effect of various oils of groundnut, olive and coconut oil were studied by incorporating them at $1 \% \mathrm{v} / \mathrm{w}(1 \mathrm{ml} / 100 \mathrm{~g}$ of substrate) into the production medium.

\section{Determination of Supplementary Carbon Sources}

The effect of different carbon sources as additional nutrients for lipase production were studied, lactose, sucrose, glucose, fructose and maltose were studied by incorporating them at $2 \% \mathrm{w} / \mathrm{w}(2 \mathrm{~g} / 100 \mathrm{~g}$ of substrate) into the production medium.

\section{Determination of Supplementary Nitrogen Sources}

The effect of nitrogen sources as additional nutrients on lipase production were malt extract, yeast extract, and urea were studied by incorporating into the production medium at $5 \% \mathrm{w} / \mathrm{w}(5 \mathrm{~g} / 100 \mathrm{~g}$ of substrate) level.

\section{Determination of Suitable Inoculum Level}

To study the effect of inoculum level on lipase production, different levels of inoculum like $1 \mathrm{ml}, 2 \mathrm{ml}, 3 \mathrm{ml}, 4 \mathrm{ml}$, and $5 \mathrm{ml}$ $(\mathrm{v} / \mathrm{w})$ were incorporated into the production medium.

\section{Determination of Optimum Incubation Period}

To study the effect of incubation period on lipase production, the flasks were incubated for varying periods of $24,48,72$, and $96 \mathrm{hrs}$.

\section{Determination of Optimum Initial pH}

To study the effect of initial medium $\mathrm{pH}$ on lipase production, the initial $\mathrm{pH}$ of the production medium was adjusted to between pH 5.0, 6.0, $7.0,8.0$ and 9.0 respectively prior to the sterilization with $\mathrm{HCl}$ or $\mathrm{NaOH}$.

Determination of Optimum Incubation Temperature To study the effect of incubation temperature on lipase production, the fermentation was carried out at various temperatures from $30^{\circ} \mathrm{C}, 40 \mathrm{oC}, 50 \mathrm{oC}, 60^{\circ} \mathrm{C}$ and $70 \mathrm{oC}$, keeping all other conditions at their optimum levels.

\section{Determination of Suitable Initial Moisture Content}

To study the effect of initial moisture content, ten flasks each containing $10 \mathrm{~g}$ of substrate shall be used and distilled water will be added to obtain various levels of moisture ranging from $10 \%$ to $100 \%(\mathrm{v} / \mathrm{w})$.

\section{Production of Lipase with Optimized Parameters}

To obtain the maximum lipase production, the SSF process was carried out by employing all the above optimized conditions. Simultaneously the fermentation process was also carried out using the initial conditions as a control (Prakash and Mukesh, 2012).

\section{Enzyme Extraction and Recovery}

Extraction of lipase from the medium after the completion of fermentation process was carried out using distilled water. Ten volumes of distilled water per gram substrate was taken in the flasks and agitated in an orbital shaking incubator $(200 \mathrm{rpm})$ at $45^{\circ} \mathrm{C}$ for $30 \mathrm{~min}$. The content was centrifuged at $10,000 \mathrm{rpm}$ and $4^{\circ} \mathrm{C}$ for $15 \mathrm{~min}$. The supernatant was used as an enzyme source (Salameh and Juergen, 2009). 


\section{Lipase assay}

The lipase activity was measured spectrophotometrically employing the method of Prakash and Mukesh,2012. The lipase activity was expressed in units per gram of substrate. Crude enzymes extract was prepared from the culture supernatant which was centrifuged at $10,000 \mathrm{rpm}$ for $15 \mathrm{mn}$ at $40 \mathrm{C}$ in $100 \mathrm{mM}$ phosphate buffer ( $\mathrm{pH} 7.0$ ), Licia et al., (2006). The substrate for this reaction composed of solution A and B. The solution A contains $40 \mathrm{mg}$ of $\mathrm{P}$ nitrophenyl Palmitate dissolved in $12 \mathrm{ml}$ of isopropanol, solution B contains $0.1 \mathrm{~g}$ of gum Arabic and $0.4 \mathrm{ml}$ of triton $\mathrm{X}-100$ dissolved in $90 \mathrm{ml}$ of distilled water. The substrate solution was prepared by adding $1 \mathrm{ml}$ of solution $\mathrm{A}$ and $19 \mathrm{ml}$ of solution $B$, the assay mixture contained $1 \mathrm{ml}$ of the substrate, $0.5 \mathrm{ml}$ of buffer, $0.1 \mathrm{ml}$ of enzyme and final volume made up to $3 \mathrm{ml}$ with distilled water. The enzyme activity was stopped by adding $0.2 \mathrm{ml}$ isopropanol and liberation of P-nitrophenol at 450C detected in spectrophotometer at $410 \mathrm{~mm}$. One enzyme is defined as 1 mol of P-nitrophenol enzymatically released from the substrate per minute (Syed et al., 2010).

\section{Ammonium sulphate precipitation method}

The enzyme, which can be concentrated through a process called salting-out method using ammonium sulphate as a common reagent. The supernatant of the Phosphate Buffered Saline processed samples was treated with $70 \%$ ammonium sulfate maintained at $4 \mathrm{oC}$ for $20 \mathrm{hrs}$.Freshly, desiccated ammonium sulfate was used to ensure uniform and rapid dissolution. The day before use, salts of ammonium sulfate was placed overnight in $120^{\circ} \mathrm{C}$ drying oven in a l drying dish (ammonium sulfate decomposes at $220^{\circ} \mathrm{C}$ ). A clean mortar and pestle were used to carefully grind the dry ammonium sulphate to a fine powder, and the ground powder was used immediately. To achieve 70\% saturation, 43.6 grams $/ 100 \mathrm{mls}$ was used by adding the powder slowly but steadily with thorough mixing. Precipitate was allowed to form for 30 minutes at $4^{\circ} \mathrm{C}$ while stirring the mixture. The precipitate was recovered by centrifugation. Solutions highly saturated in ammonium sulfate are quite dense and it can be difficult to pellet the precipitate. The supernatant was centrifuged (refrigerated tempt) at $10000 \mathrm{rpm}$ for 20 minutes. Supernatant was removed by re-spinning briefly to clear remaining ammonium sulfate while the pellets where re-suspended in a volume of buffer ( $0.1 \mathrm{M}$ phosphate buffer) equal to the volume of the sample (Anna and Sanaa, 2014).

Dialysis (Molecular Weight Cut Off separation) method This is a measure of filtration with sensitivity to pore size. The dialysis membranes are usually made of a film of regenerated cellulose esters and have MWCOs ranging from 2-50,000kDa. The precipitated samples were dialyzed to remove unwanted molecules from the samples (Valery et al., 2014).

\section{Total Protein Estimation by Lowry's Method}

Reagents used for estimation of the protein content include:
(1) BSA stock solution $(1 \mathrm{mg} / \mathrm{ml})$,

(2) Analytical reagents:

a) $50 \mathrm{ml}$ of $2 \%$ sodium carbonate mixed with $50 \mathrm{ml}$ of $0.1 \mathrm{~N} \mathrm{NaOH}$ solution $(0.4 \mathrm{gm}$ in $100 \mathrm{ml}$ distilled water.)

b) $10 \mathrm{ml}$ of $1.56 \%$ copper sulphate solution mixed with $10 \mathrm{ml}$ of $2.37 \%$ sodium potassium tartarate solution. Prepared analytical reagents were mixed with $2 \mathrm{ml}$ of (b) with $100 \mathrm{ml}$ of (a)

(3) Folin - Ciocalteau reagent solution (1N), commercial reagent $(2 \mathrm{~N})$ was diluted with an equal volume of water on the day of use $(2 \mathrm{ml}$ of commercial reagent + $2 \mathrm{ml}$ distilled water)

The phenolic group of tyrosine and trytophan residues (amino acid) in a protein produces a blue purple color complex,with maximum absorption in the region of 660 nm wavelength, with Folin- Ciocalteau reagent which consists of sodium tungstate molybdate and phosphate. Thus, the intensity of color depends on the amount of the enzymes present and thus vary for different proteins. Most proteins estimation techniques use Bovin Serum Albumin (BSA) universally as a standard protein, because of its low cost, high purity and ready availability. The method is sensitive down to about $10 \mu \mathrm{g} / \mathrm{ml}$ and is probably the most widely used protein assay despite its being only a relative method, subject to interference from Tris buffer, EDTA, nonionic and cationic detergents, carbohydrate, lipids and some salts. The incubation time is very critical for a reproducible assay. The reaction is also dependent on $\mathrm{pH}$ and a working range of $\mathrm{pH} 9$ to 10.5 is essential.

Different dilutions of BSA solutions were prepared by mixing stock BSA solution $(1 \mathrm{mg} / \mathrm{ml})$ and water in the test tube as given in the table. The final volume in each of the test tubes is $5 \mathrm{ml}$. The BSA range is 0.05 to $1 \mathrm{mg} / \mathrm{ml}$. From these different dilutions, $0.2 \mathrm{ml}$ enzyme solution was pippeted to different test tubes and $2 \mathrm{ml}$ of alkaline copper sulphate reagent (analytical reagent) was added and the solutions mixed thoroughly. The solution was incubated at room temperature for $10 \mathrm{mins}$, then added $0.2 \mathrm{ml}$ of reagent Folin Ciocalteau solution (reagent solutions) to each tube and incubate for $30 \mathrm{~min}$. Zeroed colorimeter with blank, and the optical density (measured the absorbance) at $660 \mathrm{~nm}$ was taken. The absorbance against protein concentration was plotted to get a standard calibration curve. The absorbance of unknown sample was used to determine the concentration of the unknown sample using the standard curve plotted.

\section{RESULTS}

Isolation of Bacteria isolate from soil samples in the present study four soil samples from Abattoirs were collected from different location, Kawo Abattoir and Central market Abattoirs, Nigeria respectively. The choice of areas was based on places with higher probability of lipase producing bacteria due to high level of fats accumulated by activities of butchers.

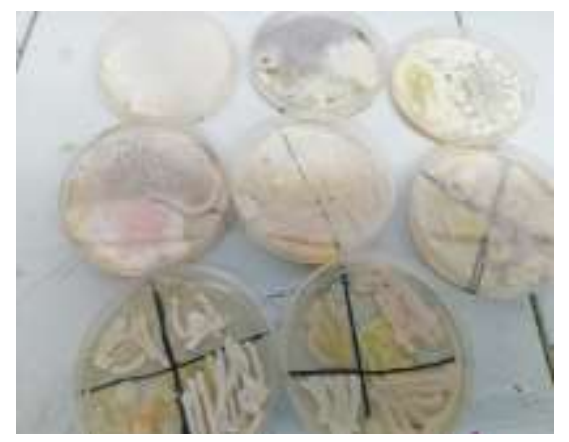

FIGURE 1: Growth of bacteria on Nutrient Agar

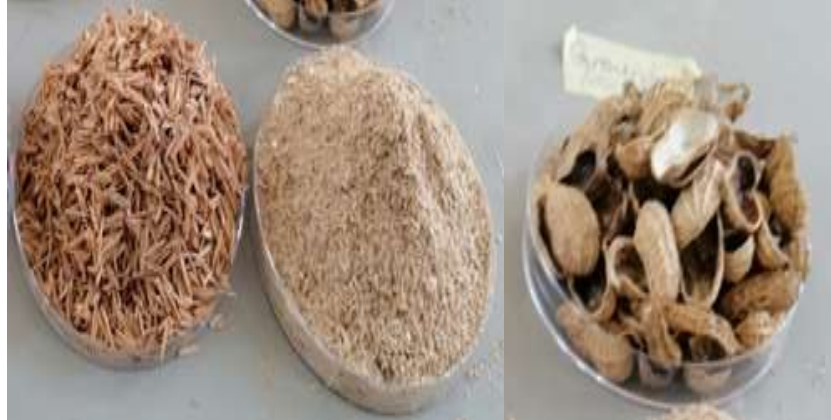

FIGURE 2: Agro Industrial Wastes 
Bacterial samples were sub-cultured on nutrient agar plates using streaked method. Individual colonies were used for further studies. The collected soil sample were processed for the isolation of various bacteria species. For this purpose, soil samples were itially cultured on nutrient agar using streaked method (Figure 1).

A total of 10 different bacterial isolate were obtained from the agar cultures. Size, colour and morphology of the colony were some of parameters that was employed in selecting colonies. The isolated colonies were subsequently tested for their abilities to produce lipases.

\section{Screening of lipase producing bacteria}

The isolated bacteria were screened on tributyrin agar plates for selecting the organisms with the potential of producing lipase (Figure 2). The bacterial isolate was streaked on tributyrin agar supplemented plates with tributyrate and incubated for 48hours. Formation of clear zone around colonies indicated lipase production.

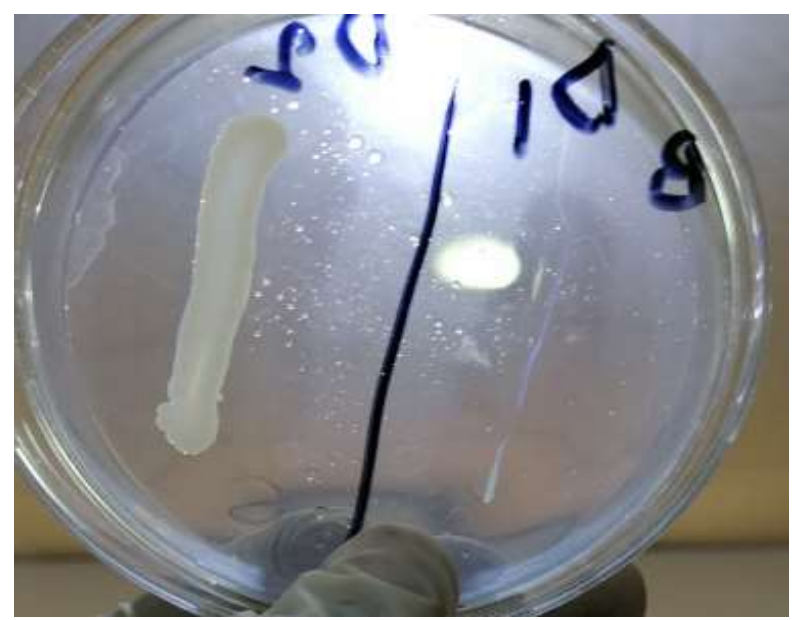

FIGURE 3: Screening of lipase producing bacteria on tributyrin agar plate formation of clear zone around colonies indicates potential lipase production by bacteria.

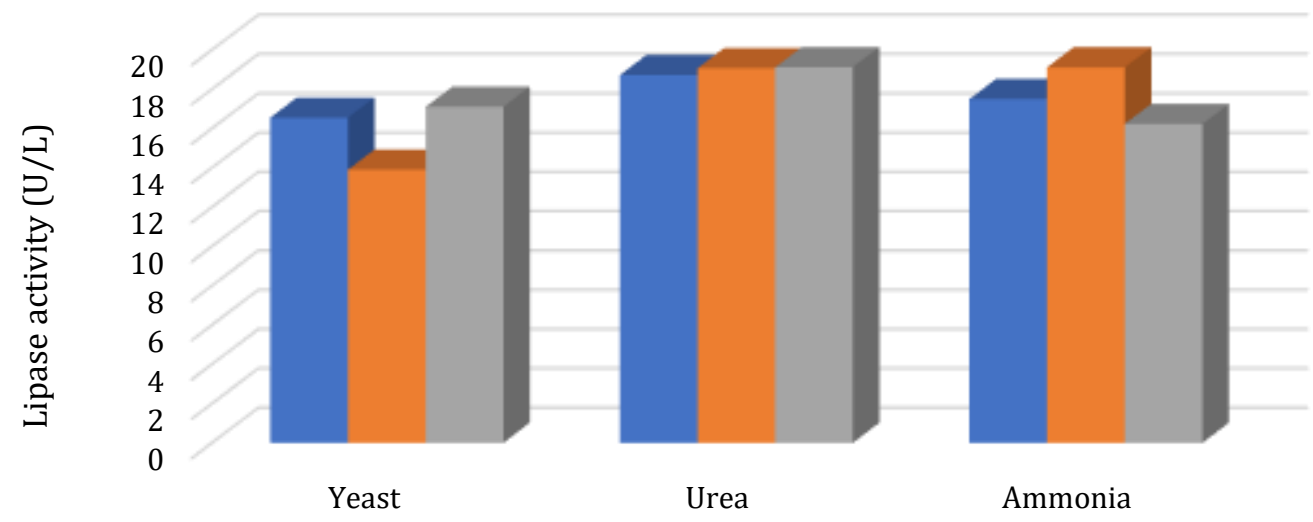

Nitrogen source

$\square$ W/bran $\quad \square$ R/husk $\quad$ Gnut peel

FIGURE 4: Effect of Nitrogen Sources

Medium containing different nitrogen sources was used as lipase producing medium to determine the effect of different nitrogen sources (yeast extract, malt extract and urea) on production of lipase media were incubated at 370C, pH 7 for 48hrs. supernatants were taken after centrifugation at $10,000 \mathrm{rpm}$ to assay the lipase activity using spectrophometric method.
Lipase activity was considerably higher in urea with $19.11 \mathrm{u} / \mathrm{L}, 19.06 \mathrm{u} / \mathrm{L}, 18.71 \mathrm{u} / \mathrm{L}$ for groundnut peel, rice husk and wheat bran, followed by Ammonium nitrate supplemented media with $19.10 \mathrm{u} / \mathrm{L}, 17.49 \mathrm{u} / \mathrm{L}$ and $16.22 \mathrm{u} / \mathrm{L}$ for rice husk, wheat bran and groundnut peel respectively. Activity of $17.09 \mathrm{u} / \mathrm{L}, 16.54 \mathrm{u} / \mathrm{L}$ and $13.8 \mathrm{u} / \mathrm{L}$ was recorded for yeast supplemented media.

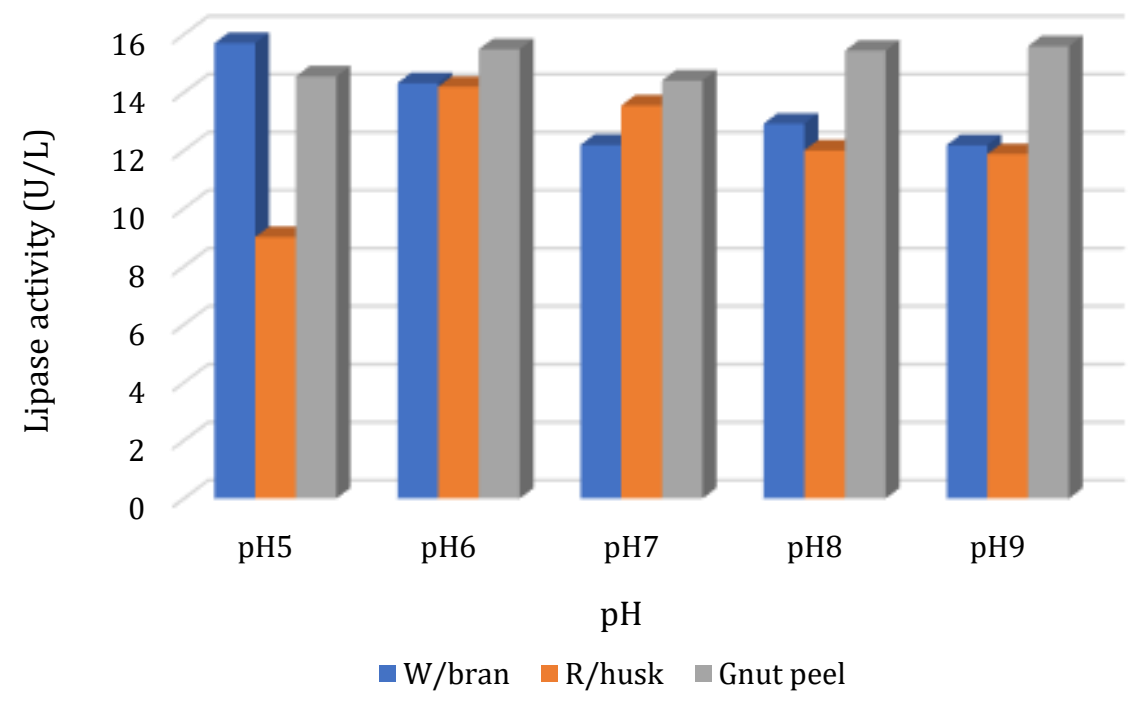

FIGURE 5: Effect of initial $\mathrm{pH}$ 
Media containing wastes media was used to determine the effect of different $\mathrm{pH}(5,6,7,8$ and 9$)$ on lipase production, cultures were grown in production media of different $\mathrm{pH}$ while maintaining all other conditions of fermentation.
Supernatants were collected after centrifugation and used for lipase assay using spectrophotometric method. Results showed that highest activity was recorded in wheat-bran waste media $15.70 \mathrm{u} / \mathrm{l}$ at $\mathrm{pH} 5$ followed by $\mathrm{G} /$ nut peel media with $15.59 \mathrm{u} / \mathrm{L}$ at $\mathrm{pH} 9,15.49 \mathrm{u} / \mathrm{l}$ at $\mathrm{pH} 6$ and 15.44 at pH8.

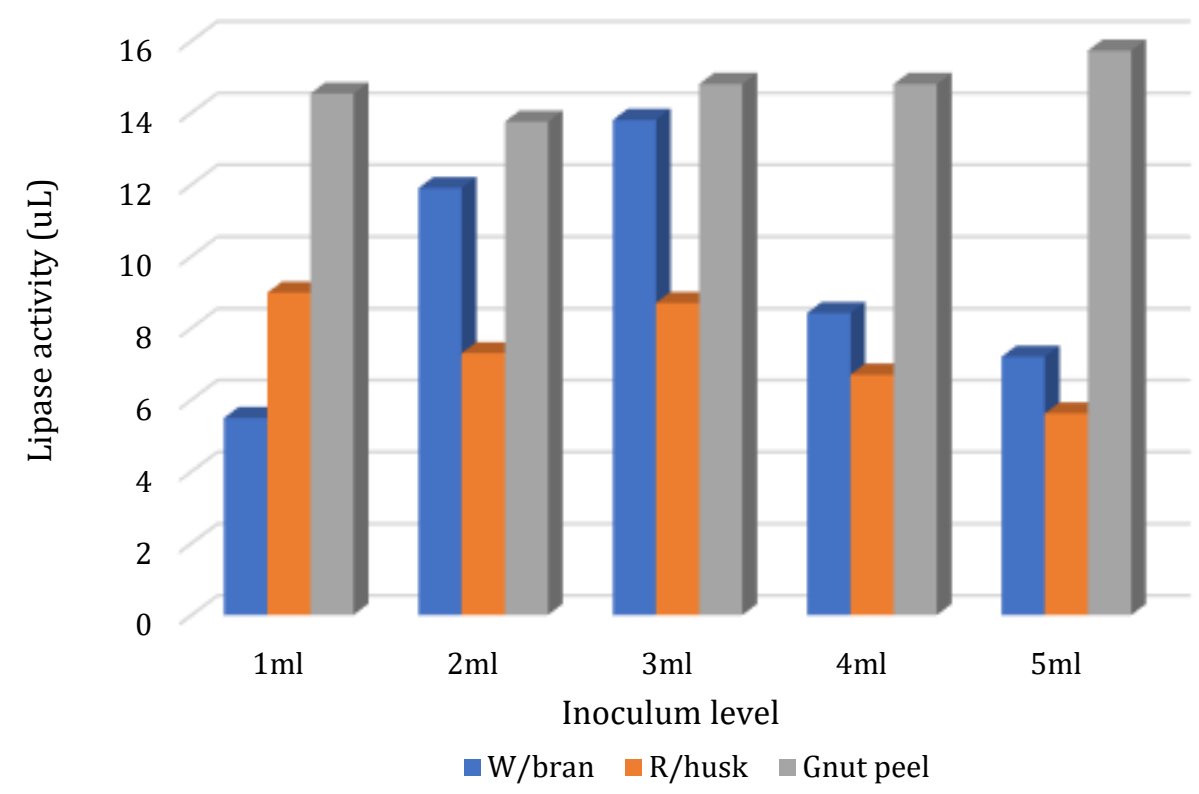

FIGURE 6: Effect of Inoculum Level

Waste media inoculated with different inoculums level was as lipase production media (1mL, $2 \mathrm{~mL}, 3 \mathrm{~mL}, 4 \mathrm{~mL}$ and $5 \mathrm{~mL})$ at pH 7 over a period of $48 \mathrm{hrs}$ and supernatants taken to assay for lipase activity using spectrophotometric method. The highest activity recorded was $15.72 \mathrm{u} / \mathrm{mL}$ obtained from media containing $5 \mathrm{ml}$ inoculums level.

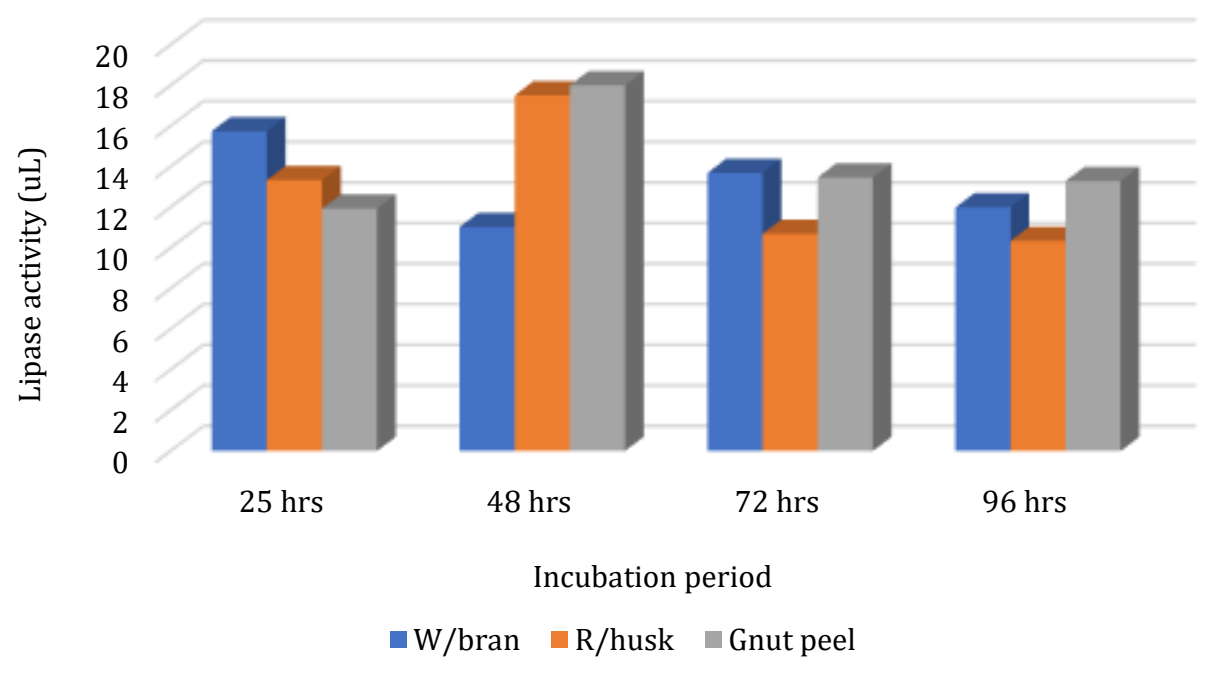

FIGURE 7: Effect of Incubation Period

Waste media was used as lipase production media to determine the effect of incubation period for the production, different incubation period was considered for incubation $(24,48,72$ and $96 \mathrm{hrs})$ and supernatants were taken after centrifugation to assay for lipase activity using spectrophotometric method. Lipase activity was prominent after 48hrs of incubation in the media containing ground peel with $18.00 \mathrm{u} / \mathrm{L}$ and incubation in the media containing ground peel with $18.00 \mathrm{u} / \mathrm{L}$ and $17.50 \mathrm{u} / \mathrm{L}$ for rice husk waste at $48 \mathrm{hrs}$ respectively. 4 


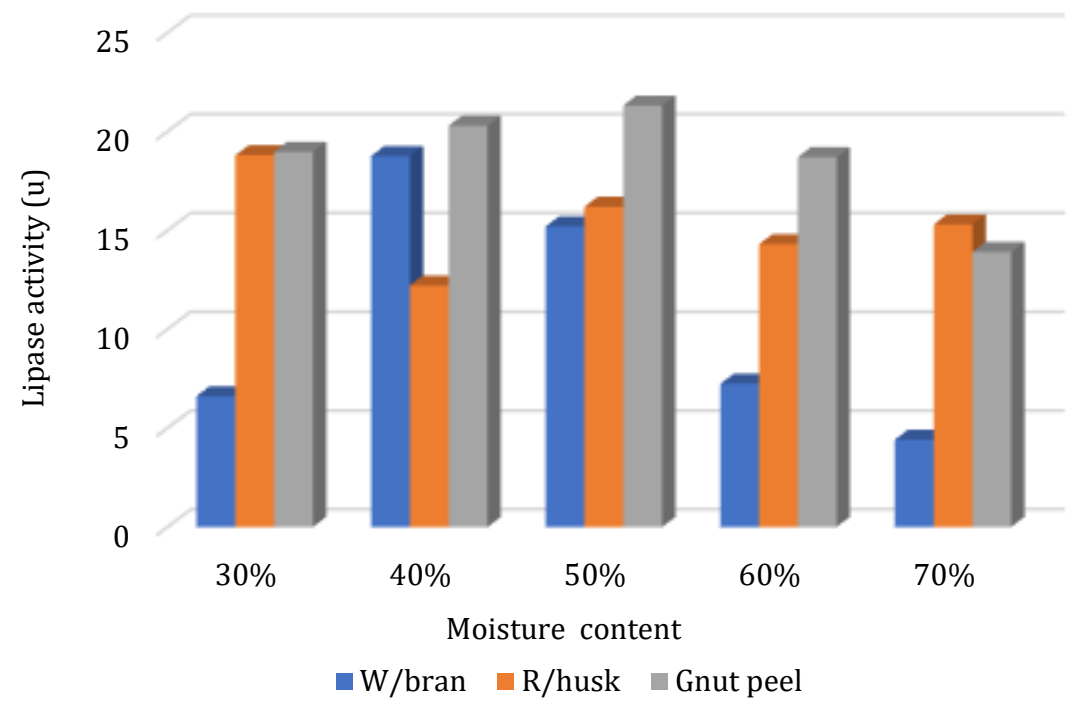

FIGURE 8: Effect of Moisture Content

Waste media used as production media for production of lipase at different levels of moisture was considered for optimal production of lipase $(30,40,50,50$ and $70 \%)$ after incubation supernants was obtained after centrifugation and assay for lipase activity was carried out using spectrophotometric method.

The least activity was recorded at higher level of moisture (70\%) in wheat bran, while the optimum activity was at $40 \%$ moisture $20.30 \mathrm{u} / \mathrm{L}$ for medium containing groundnut peel.

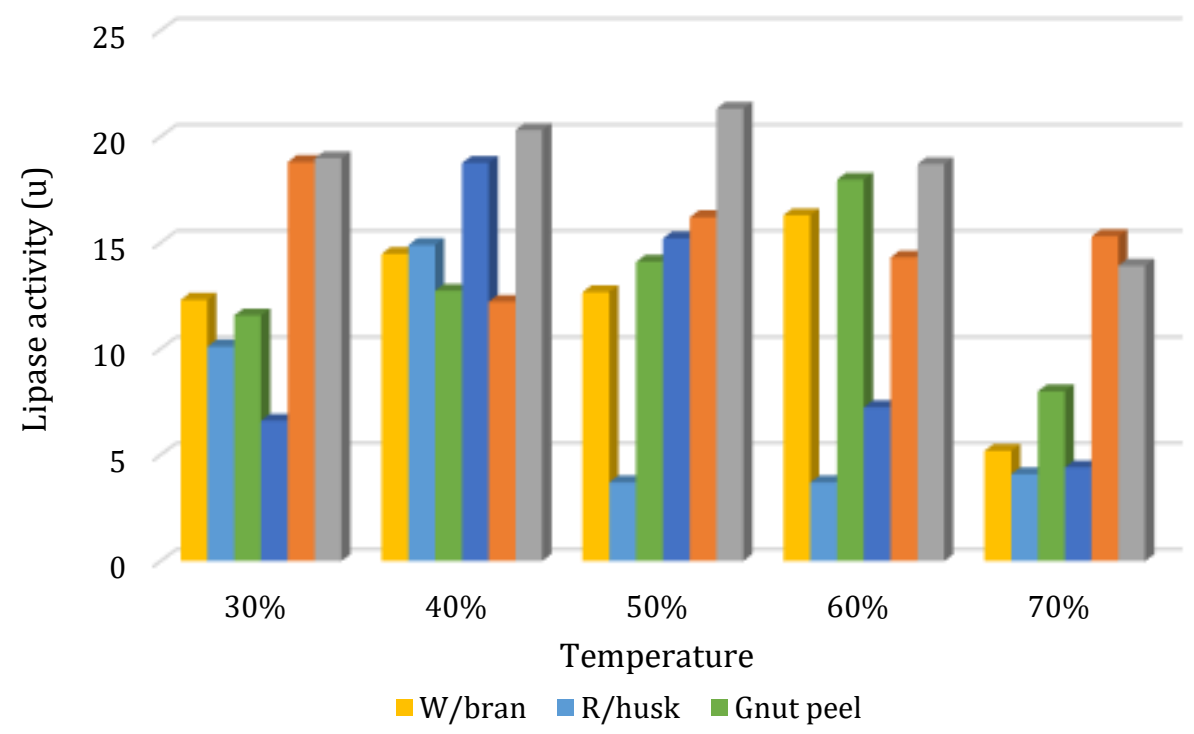

FIGURE 9: Effect of Temperature

Wastes media was used to determine the effect of different levels of temperature for the production of lipase while maintaining all other conditions of fermentation. After incubation and centrifugation, supernantants were collected for lipase activity assay using spectrophotometric method. Highest activity was recorded at 500C in the media containing groundnut peel at $1797 \mathrm{u} / \mathrm{L}$ and $16.29 \mathrm{u} / \mathrm{L}$ for wheat bran at $500 \mathrm{C}$.

\section{DISCUSSION}

Lipases are important enzymes because of their vast array of industrial use, they belong to the group of hydrolases catalyzing the hydrolysis of traglycerol there by having numerous industrial applications in food, diary, cosmetic, oleo chemicals, pharmaceuticals and detergents industries. These enzymes are widely present in many organisms including microorganisms. Pseudomonas lipases are especially interesting due to their high activity at alkaline and neutral $\mathrm{pH}$.
In present study, screening samples collected from different abattoirs as described in the materials and methods have indicated the presence of lipase producing stains.

Although different bacterial isolates obtained showed lipase activity, however strain found in soil sample from central market abattoir showed a wider zones of inhibition and the one with clear and wider zone was picked for further studies and optimization.

It is obvious from the isolates that lipase producing organisms are present everywhere irrespective of habitats and localities even though, some places can be richer from lipase producing organisms than the others.

A total of 26 bacterial isolates were obtained on nutrient agar based on their colony morphology size and color and screened on Tributyrin Agar plates, colony with the clearer zone was selected for lipase activity. 
The lipase producing organism upon identifying and isolating organisms with highest activity, different growth conditions that influences the production of lipase were varied using one variable at a time approach for the optimization of lipase production.

The lipase producing bacterial isolates were studied for morphological characteristic according to standard microbiological protocols based on color, size, culture and shape of the colony. In this work the colony with the cleaver and wider zones was selected and identified as pseudomonas specie on the basic of morphological and biochemical tests according to Bergey's manual of determinative bacteriology (Figure 1).

The cells free crude lipase produced by pseudomonas isolate were partially purified up to $70 \%$ saturation using ammonium sulphate.

Starting with inducers highest lipase activity was recorded in wheat bran wastes supplanted with coconut oil and groundnut oil with activity of $16.49 \mathrm{u} / \mathrm{mL}$ while groundnut peel media supplemented with olive oil also showed higher activity of $15.99 \mathrm{u} / \mathrm{mI}$. This result indicates that apart from olive oil used as inducers by most researchers, other oils has proving to be promising in inducing lipase production.

Nitrogen sources were varied, nitrogen was supplied to the growth media with enhance cell growth factors and amino acids necessary for enzyme synthesis (Thakur et al., 2014) of the three sources of nitrogen used groundnut peel media supplemented with urea indicates with highest activity with $19.11 \mathrm{u} / \mathrm{mL}$ and $19.06 \mathrm{u} / \mathrm{mL}$ respectively. Rice husk supplemented with Ammonia with activity of $19.10 \mathrm{u} / \mathrm{mL}$. in order to determine the optimum $\mathrm{pH}$, high lipase activity recorded in the $\mathrm{pH}$ range of $5-8$ in all the media, but groundnut peel media with $\mathrm{pH}$ range of $5-9$. Maximum activity of all the isolates were observed at $\mathrm{pH} 6$, however it was observed that lipase activity decreased directly with increase or decrease in $\mathrm{pH}$ of the production medium. Bacteria with lipase producing ability have been reported to prefer $\mathrm{pH}$ around 7 or 6 , however maximum activity have been reported in higher pH (Gupta et al., 2004).

Salihu et al., (2012) reported that inoculums level has a direct proportional effect on lipase activity. In groundnut peel media the activity was higher with $5 \mathrm{ml}$ inoculums level, however, Thakur et al., 201 reported inoculums level is inversely proportional to lipase activity since cells are competing for nutrients as observed in wheat bran media that had highest activity at $2 \mathrm{ml}$ and $3 \mathrm{ml}$ inoculums level but decreases with increase in inoculums level $(5 \mathrm{~mL})$ at $7.19 \mathrm{u} / \mathrm{mL}$. for the hours taken for fermentation incubation period was varied for the growth of organisms, the highest activity was recorded at $48 \mathrm{hrs}$ period, this shows that the more the period of incubation, depletion could be related to consumption of nutritional elements (Gupta et al., 2004)). Highest activity was observed at $50 \%$ for groundnut peel media at $21.31 \mathrm{u} / \mathrm{mL}$ and $40 \%$ for groundnut peel and wheat bran at $20.30 \mathrm{u} / \mathrm{mL}$ and $18.76 \mathrm{u} / \mathrm{mL}$ respectively. For the degrees of temperature, the least activity was at $500 \mathrm{C}$ for rice husk at $3.70 \mathrm{u} / \mathrm{mL}$ while the highest activity was at $500 \mathrm{C}$ for groundnut peel waste media.

\section{CONCLUSION}

Lignocellulosic waste from the Agricultural sector is one of the cheapest and readily available form of carbon sources for the production of value-added products such as enzymes. Both bacterial and fungal species can be deployed for production of various enzymes using agro wastes.
Solid state fermentation from all indication triumph over submerged fermentation methods because it mimics the natural conditions that favours microbial growths for higher enzymes yield. An extensive analysis of several studies on the use of inexpensive media components for enzymes production has shown that lignocellulosic agro wastes is more promising and can be utilized as a carbon source in mainstream upscale fermentation processes.

\section{REFERENCES}

[1] Anna, K.K., and Sanaa, B.A. (2014): Purification, characterization of Thermostable Amylopullulanase from Bacillus licheniformis (BS18) by using solid state fermentation (SSF), J. Baghdad for Sci. Vol.11 (2)

[2] Bergy D.H., Breed R.S. (1957) American Society of Microbiology. Bergey's manual of determinative bacteriology 7 th edition.

[3] Gupta, R., Gupta A. Kumari P. Rathi. Bacterial lipases: an overview of production, purification and biochemical properties, Appl, J. Microbiol, Biotechnol. 64 (2004) 763-768.

[4] Lowry, O. H., Rosebrough, N.J., Farr, A.L., and Randall, R.J. (1951) J.Biol.Chem 193: 265 (The original method).

[5] Martins, V.G. Kalil, S.J., Costa, J.A.(2008) Co-producao de lipase e biossurfactante em estado solido para utilizacao em biorremediacao de oleos vegetais e hidrocarbonetos Quimeca Nova,31,p.1942-1947.

[6] Marwah,R.G., Saxena,R.K., Gupta,R. (2000)Fermentation and Downtream processing of lipases from Aspergillus terreus.Process Engineering Vol 19(3) pp149-155

[7] Messias, J.M. Costa da,B.Z., Lima de,V.M.G., Giese,E.C., Dekker, R.F.H., Barbosa, A.M. (2011) Lipases microbianas: producao,propadiades e aplicacoes biotecnologicas,Semina :Ciencias Exatas e Technologicas, 32, p. 213-234.

[8] Panesar, P.S., Kaur, R., Singla, G., Sangwan, R.S. (2016) Bioprocessing of Agro-industrial wastes for production of food grade enzymes: Progress and prospects. Applied Food Biotechnology3(4),208-227

[9] Prakash, T. Mukesh, U. (2012). Characterization of a thermo tolerant lipase from picjia anamola. European Journal of Experimental Biology 2 (3): 464-4

[10] Ravindran R., Hassan S., Williams, A.G. and Jais Wal, K.A (2018). Biotransformation of Agric Food Waste Into High - value products. Bioengineering 5(4):93

[11] Salameh M.A., Juergen, W. (2009). Synthesis of fatty acid esters and diacylglycerols at elevated temperature by alkalithermophilic lipase from thermosyntropha lipolytica. J Ind Microbial Biotechnol 10:610-3

[12] Salihu, A. Alan, M. Abdulkarim, M. Salleh, H. (2012) Lolade production: as insight in the utilization of renewable agriculture residues, Resour. Consery, Recycl. 58 36-44.

[13] Syed, M.N., Iqbal S., Bano S., Khan A. Ali-ul-Qader S., Azhar A. (2010) Purification and characterization of 60 KD lipase linked with Chaperonin from Pseudomonas aeruginosa BN-1. African Journal of Biotechnology Vol.9 (45) pp7724-7732 
[14] Thakur, V., Tewari, R., Sharma, R. (2014) Evaluation of production parameters for maximum lipase production by P. Stutzeri MTCC 5618 and scale-up bioreactor. Chin. J. Biol. 1-14.

[15] Tosh, W., Sudhir, K.J (2017). Isolation, screening and identification of lipase producing fungi from oil. Contaminated soil of shani Mandir Ujjain. Int. J. curr. Microbial. App sci 6(7):1872-1878.
[16] Valery, B., Vladimir, S., and Ivan, D., (2014): Obtaining Bacteriocins by Chromatographic Methods, Advances in Bioscience and Biotechnology, 446-451. 